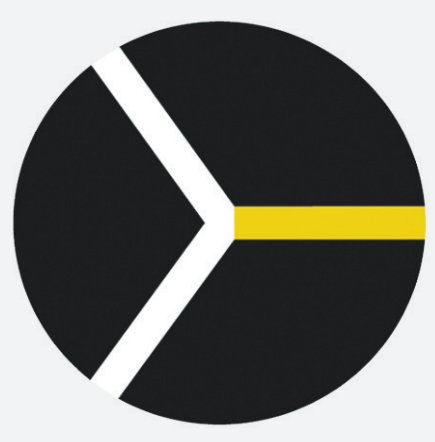

TECHNOLOGY GOVERNANCE

Working Papers in Technology Governance and Economic Dynamics no. 44

THE OTHER CANON FOUNDATION, NORWAY

TALLINN UNIVERSITY OF TECHNOLOGY, TALLINN

CONTACT: Rainer Kattel, kattel@staff.ttu.ee; Wolfgang Drechsler, drechsler@staff.ttu.ee; Erik S. Reinert, reinert@staff.ttu.ee

\title{
The renewable energies technology surge: A new techno-economic paradigm in the making?
}

John A. Mathews*

August 2012

* Professor of Management Macquarie Graduate School of Management, Macquarie University, Sydney, Australia, 2109 Email john.mathews@mgsm.edu.au
* Eni Chair in Competitive Dynamics and Global Strategy LUISS Guido Carli University

Viale Romania 3200197 Roma Italy

Email jmathews@luiss.it 


\begin{abstract}
Despite discussion of a 'carbon lock-in' and techno-institutional barriers to change, energy studies have had little serious contact with neoSchumpeterian theorizing on technological 'surges' or revolutions and successive waves of creative destruction, which have characterized the entire industrial era from the 1770 s on. In this paper a way is offered to link the current surge in renewable energy investment to the theorizing over long (Kondratiev) waves and techno-economic paradigm shifts. The paper argues that the current renewable energy surge can be best comprehended as a secondary surge in the fifth long K-wave, coinciding with the shift from gestation to installation of a new sixth techno-economic paradigm within the matrix of the fifth. It is argued that this emergent $6^{\text {th }}$ paradigm is a continuation and fulfilment of the $5^{\text {th }}$, where IT and ICT are applied to the electric power grid, and that both are in conflict with the still-incumbent $4^{\text {th }}$ paradigm based on fossil fuels and centralized power generation. The emergent $6^{\text {th }}$ paradigm portends a renewable energy speculative financial boom and bubble which could burst sometime in the period 2015 to 2020, ushering in a period of sustained development of renewables and energy-efficiency services by productive rather than financial capital.
\end{abstract}

Keywords: renewable energies; techno-economic paradigm shift; technology surge; neo-Schumpeterian dynamics; creative destruction

\title{
1. Introduction
}

In this paper I confront the paradox that the forthcoming revolution in energy technology, widely perceived to be essential to curbing carbon emissions and saving our industrial civilization, is discussed with barely any reference to the established literature on innovation and entrepreneurship, creative destruction and shifts in techno-economic paradigms. There is such a large and influential literature covering these topics - and yet it barely engages with the current discussion of the need to shift from fossil-fuelled energy systems and nuclear power systems to $100 \%$ renewable energy systems. The debates over 'innovation' proceed in a leisurely way as if everything of interest happened only up to the advent of the era of ICT and microelectronics, while the discussions of the shift to renewable energies (REs) take place innocent of any insights derived from Schumpeterian, neo-Schumpeterian or paradigm-shift reasoning. In particular, the key question as to how to accelerate the rate of uptake of the renewable energies is conducted in an intellectual setting framed almost exclusively by neoclassical economics (in terms of carbon taxes, emissions trading schemes or hybrids of the two) - and yet these inter- 
demonstrable effect in the next decade. The neo-Schumpeterian contribution to the debate has, by contrast, been negligible.

In the energy field, we find a characterization of a fossil-fuel-based Techno-Institutional Complex (TIC), termed 'carbon lock-in' by Unruh (2000; 2012), as well as papers on socio-technical barriers to change (e.g. Sovacool 2009a; -b). Despite the fact that these papers contain no references to Kondratiev, Schumpeter nor Perez, they nevertheless shed light on the institutional underpinnings of the age of oil, and give some insight into the scale of the techno-economic and institutional upheavals that will be needed to bring forth an era of renewable energies. I take carbon lock-in as a central feature of the oil-based fourth techno-economic paradigm and its extension into the fifth paradigm based on IT/ICT, and the breaking of carbon lock-in via creative destruction to be the key challenge for the emergence of a new era based on renewable energies.

In this contribution, then, I propose to discuss the shift in energy systems from the present conventional, incumbent, fossil-fuelled and nuclear power systems to those based on renewable resources - solar, wind and bioenergy - and do so in a framework of techno-economic paradigm shift. I do this in order to investigate whether this sheds light on the process, and whether it generates insight in particular into the policy considerations involved.

That there is indeed a greening of industry under way - and in particular a greening of energy systems - seems to be beyond serious doubt. The evidence is abundant. There is for example data on investment and new capacity creation, which is being directed more and more towards green, renewable energy options. By 2011 new installed capacity in green power generation (plus nuclear?) accounted for just under one half of all capacity additions, thus matching those of thermal power generation; this is a tipping point of enormous significance. As shown in Fig. 1, investment has been rising rapidly, reaching \$254 billion in the year 2011 and expanding by more than $50 \%$ per year (smoothing out the effect of the GFC). What is even more striking in the current surge of additions to renewable energy is that China has emerged as by far the strongest player, now accounting for the largest share in capacity additions, in actual investments, in installed base, and in terms of companies entering the global Top Ten particularly in wind power, in solar photovoltaics and

1 Capacity additions to global electric power generation systems in 2011 were $208 \mathrm{GW}$, with renewable energy systems accounting for $102 \mathrm{GW}$ and thermal power systems accounting for just a fraction more, at $106 \mathrm{GW}$ : see the Ren21 report Renewables 2012: Global Status Report. 2 See the latest report from Bloomberg New Energy Finance, Global Trends in Clean Energy Investment, 202012 (BNEF 2012). 
in smart grid technology. China's emergence as leader is yet another indication of the fundamental shift in techno-economic characteristics of global energy systems that is under way (Ren21 2012).

Fig. 1 New investment in clean energy, 2004-2012 (quarterly)

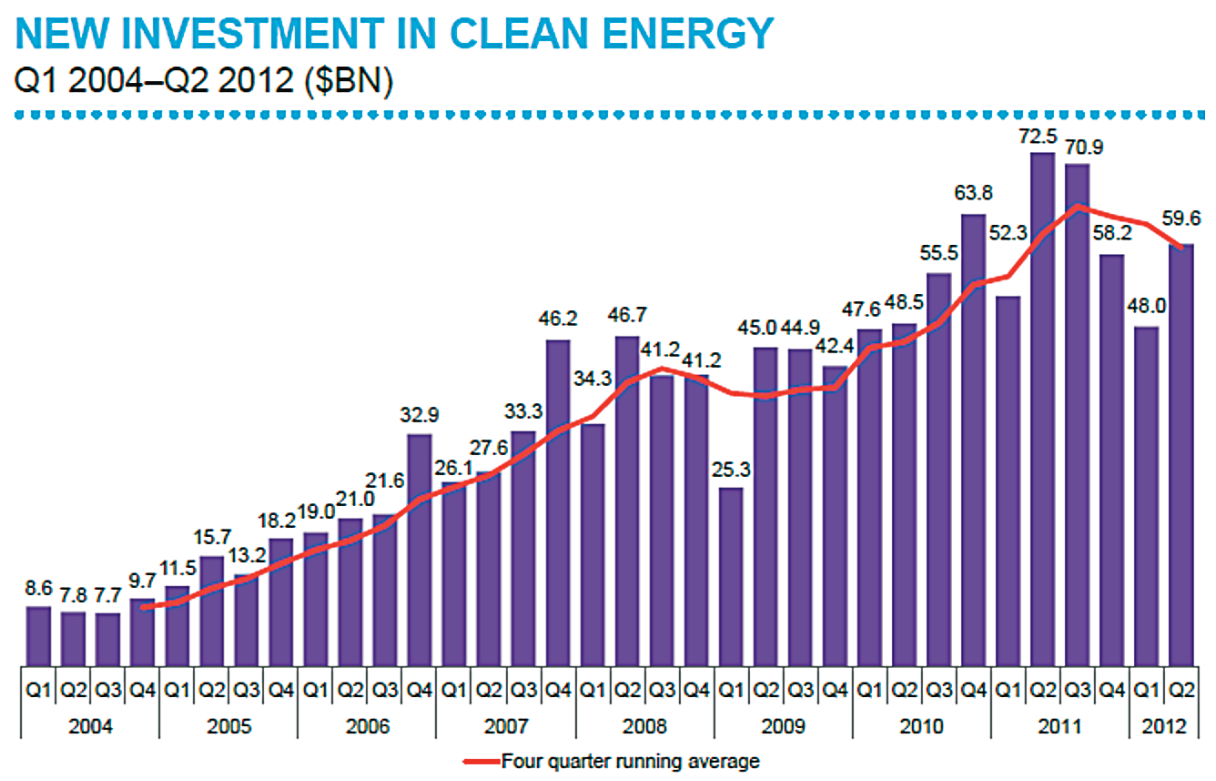

Note: Total values include estimates for undisclosed deals. Excludes corporate and government R\&D. Now includes small distributed capacity \& adjustment for re-invested equity. NEW

Source: Bloomberg New Energy Finance

\section{Technology cycles in the era of industrialization}

The advent of industrialization brought in its wake an entirely new phenomenon - a cyclical pattern to industrial growth that came to be known as business cycles. The characterization of periods of upsurge (upswings) and downswings, across the entire global capitalist economy, is subject to a great deal of strenuous scholarly effort and disagreement - and so in the absence of any definitive study of the economic history of the industrial era, we have to pose our assertions with some degree of caution. The first systematic investigations of the topic were conducted by the Russian scholar Nikolai Kondratiev. ${ }^{3}$ Subsequently it was Schumpeter who made the decisive contribution, arguing in his Business Cycles (1939) that each successive long wave is associated with an investment

3 Kondratiev did his work in Russia in the 1920s, before being imprisoned by the Bolshevik regime. His own best-known exposition can be found in English in Kondratiev (1935). 
surge driving a new cluster of innovations. ${ }^{4}$ Most scholars are agreed that there was an upsurge in investments starting around 1770 s/1780s associated with the application of power and mechanization (water power and some steam) to previously craft production, and with drastic improvements in transport (involving canals and turnpikes) -- followed by a downswing from the 1820s to 1840s as the new industrial systems spread across Europe and through the United States. Then there was a new upswing dating from the 1840s associated with the investment surge in steam power, railroads and iron, followed by a downswing from the 1870 s to the 1890 s as again these new technologies became widespread throughout the industrial world. A third such upswing began in the 1890s, driven by a new surge in investments in steel and electric power and electric motors (giving rise to the skyscraper, amongst other aspects of modernity), and a downswing following the First World War associated with the diffusion of mass production and the automotive industry, leading into the depressed 1930s. Most scholars would recognize a fourth upswing following the Second World War driven by huge investments in oil-based expansion of industry, transport, suburbanization and the spread of mass consumption. Some scholars have identified a fifth such upswing since the 1980s, associated with IT, computerization and telecommunications, where the technology surge of the 1990s was linked to the financial bubble that burst in 2000 .

It is clear why such an account of technological surges remains on the margins of neoclassical economics. If this account, or something like it, were to be accepted generally, it would contradict the widely held assumption by economists that technological changes are exogenous and random - and if this assumption were to be taken away, with it would fall the entire edifice of neoclassical economics, with its production functions, equilibrium, and all its other paraphernalia.

\footnotetext{
4 Schumpeter's massive work Business Cycles, published in two large volumes in 1939, remains the most ambitious of these explorations of industrial economic history and the phenomena of business cycles. While long on extremely insightful description it was short on rigorous statistical analysis, for which he was excoriated in a review published in 1940 by Simon Kuznets, a fellow scholar of the upswing/downswing phenomenon (but who refused to recognize it as cyclical) and who made his name as founder of national income accounting and the concept of GNP. Others have contributed more recently, notably Freeman and Perez (1988) who introduced the influential notion of 'techno-economic paradigm' to describe each successive era, associated with sweeping change associated with some new general technology.

5 Freeman (1983) provided a broad overview of the state of play in long waves research at the beginning of the 1980s. Since then, one of the most enduring contributions was that by Freeman and Perez (1988) - and in subsequent elaborations by Perez (2002) and by Freeman and Louçã (2001). Louçã (1997) provided a critique of simplistic econometric efforts to measure long waves, while Tylecote (1992) provided more historical background supporting these periodizations. Perez $(2004 ; 2009 ; 2010 ; 2011 ; 2012)$ provides further elaboration.
} 
But if instead an empirically informed view of economic evolution is allowed, then the transformations described as 'surges' are seen to be real, and in need of a serious explanation. In such a framework, it is possible to see a new round of investment in renewable energy and lowcarbon technologies as picking up from around 2010, or building on (or cutting short) the fifth cycle. Whatever the periodization and the identification of such upswings and downswings, there have clearly been periods of upsurge associated with a new general technology that enables costs and prices to be drastically reduced. The dating of the main waves (as generally accepted), is given in Table 1.

Table 1. Upswings and downswings in industrial capitalism, 1760-2011

\begin{tabular}{|c|c|c|c|}
\hline Long wave number & Phase & Onset & Ending \\
\hline $1^{\text {st }}$ & $\begin{array}{c}\text { A: upswing } \\
\text { B: downswing }\end{array}$ & $\begin{array}{c}1780 s \\
1810-17\end{array}$ & $\begin{array}{l}1810-17\left(1815^{*}\right) \\
1844-51(1848 *)\end{array}$ \\
\hline $2^{\text {nd }}$ & $\begin{array}{c}\text { A: upswing } \\
\text { B: downswing }\end{array}$ & $\begin{array}{l}1844-51 \\
1870-75\end{array}$ & $\begin{array}{l}1870-75(1873 *) \\
1890-96(1895 *)\end{array}$ \\
\hline $3^{\text {rd }}$ & $\begin{array}{c}\text { A: upswing } \\
\text { B: downswing }\end{array}$ & $\begin{array}{l}1890-96 \\
1914-20\end{array}$ & $\begin{array}{l}1914-20(1918 *) \\
1939-50(1940 *)\end{array}$ \\
\hline $4^{\text {th }}$ & $\begin{array}{c}\text { A: upswing } \\
\text { B: downswing }\end{array}$ & $\begin{array}{l}1939-50 \\
1968-74\end{array}$ & $\begin{array}{c}1968-74(1973 *) \\
1984-91\end{array}$ \\
\hline $5^{\text {th }}$ & $\begin{array}{c}\text { A: upswing } \\
\text { B: downswing }\end{array}$ & $\begin{array}{c}1984-91 \\
2008-2010 ?\end{array}$ & $\begin{array}{c}2008-2010 ? \\
?\end{array}$ \\
\hline
\end{tabular}

Source: based on Korotayev and Tsirel (2010), Tables 1, 2, p. 2; starred dates in brackets are those given by Freeman and Louçã (2001)

The world has been enjoying the upswing of the $5^{\text {th }} \mathrm{K}$-wave since the second half of the 1980s, and the recovery phase of the earlier long wave since the late 1970s, generally associated with the massive adoption of microelectronics, communications and information technologies. This

6 Actually these dates are not 'widely accepted' but they provide a starting point for further analysis. While legions of economists have over the years occupied themselves with market trivia, these most fundamental aspects of capitalist industrial dynamics have languished for want of scholarship. The Russian polymath Andrey Korotayev together with his collaborator Sergey Tsirel has recently revived the study of long waves (or K-waves, after Kondratiev (Kondratieff)) by subjecting the time series to spectral analysis - thereby providing solid proof that these waves exist (Korotayev and Tsirel 2010). 
long boom is viewed as levelling off around 2010 - which provides a plausible rationale for the global financial crisis that occurred in 2008-09. What is to follow this peaking (or the possibility of a second, minor upswing in the 2010 s driven by renewable energies) is a matter of current 'great debate'. We shall return to the uncertain dating of the peaking of the $5^{\text {th }} \mathrm{K}$-wave below.

\section{Techno-economic paradigm shifts}

The most widely accepted theoretical framework for discussing technological change, and periodic 'technology surges' and the creative destruction they generate, doing away with the old and creating space for the new, is that of Freeman and Perez, which is in turn based on a close reading of Schumpeter's business cycles and Kondratiev long wave theory. There are in fact two strands of this framework. There is Freeman $(1977 ; 1983 ; 1986)$ and Perez $(1983 ; 1985)$ and what emerged as a joint vision in Freeman and Perez (1988), where the emphasis is on the triggering of new long waves by clusters of innovations, and upswings and downswings reflecting the struggles of the new to be born and the old to refuse to die. Freeman and Perez identify five such shifts or technology surges - the latest being the surge associated since the 1970s with the introduction of IT and ICT technologies. Then there is a second strand initiated by Perez herself, where she links the technology narrative with financial investment, speculation and bubbles - as in Perez (2002; 2011). Apart from some very recent and 'casual' references to green technology, both 'Freeman \& Perez' (strand 1) and Perez (strand 2) confine themselves to the five paradigm shifts associated with surges in five technology clusters, and have spent the best part of the last two decades defending the proposition that the world has been experiencing the upheavals associated with adapting to the technical, institutional and organizational shifts spurred by the $5^{\text {th }}$ Techno-Economic Paradigm (TEP). The issue is: how well do these arguments carry over to the case of the transition to green technology and Renewable Energies (REs)?

\footnotetext{
7 Freeman and Perez (1988) was followed by further elaboration from Freeman (1989; 1991; 1996) and from Perez (1992; 2001).

8 Freeman (1996) mentions 'greening' of technology, and Freeman (1997) mentions the possibility of a new sixth techno-economic paradigm (with no dates specified), where renewable energies provide the 'energy system' but are not identified as the lead factor, and where other (improbable) features such as humanities being united with social and natural sciences are also mentioned. This seems to be the only reference by one of the 'TEP' scholars to a potential sixth paradigm and to renewable energies. Perez in her most recent writings certainly refers to greening of technology as a necessary way forward - but nowhere seems to link this to her historical, technological nor financial drivers of change.
} 
Perez herself provides the key to making the connection in her notion that while the dominant TEP moves through its mature phases (late deployment and decline) the new paradigm is gestating and moving into earlyphase installation. My argument, in a nutshell, is that this is precisely what is occurring with the case of REs.

Perez (1986) identifies a 'key factor' with each TEP, and characterizes it in the following terms: it has declining relative costs; its supply is virtually unlimited; it has massive potential for applications and so for becoming pervasive; and it forms a core element of a complex of technologies, processes and institutions.

In the Freeman-Perez phase of the argument, the novel TEP is characterized by three defining criteria: 1) changes in cost structure, with the emerging technological regime enjoying strong and increasing cost advantages; 2) expanded perception of opportunity spaces, creating multiple entrepreneurial opportunities for the application of the emergent bundle of technologies; and 3) new organizational models, where the new is better fitted to the emergent technologies and generates massive gains in terms of efficiency over those linked (or constrained) by the dominant paradigm. We shall take these characterizations as definitive.

Two graphical representations of the process capture its dynamics, as shown by Perez (2011). ${ }^{9}$ The core of the technological revolution consists of two phases - one of installation, where financial capital is taking the major risks and is the driving force, and a successive phase of deployment, where productive capital takes over and the new technology and its applications are bedded down and become the new norm. But successive waves require a longer time horizon, and so Perez extends the process to a four-phase series of successive waves, where installation comes after a very early process of gestation (occurring during the deployment phase of the previous paradigm), and deployment is succeeded by a late phase of decline (and/or modernization on the part of the incumbents). Thus the four phases are those of gestation, installation, deployment and finally decline (or modernization), each succeeding each other in waves of logistic substitution (Figs 2a, b).

9 Note that this paper dates from 2003. 
Figure 2a. Installation and deployment phases in a technology surge

Figure 2: Two Different Periods in the Diffusion of Technological Revolutions

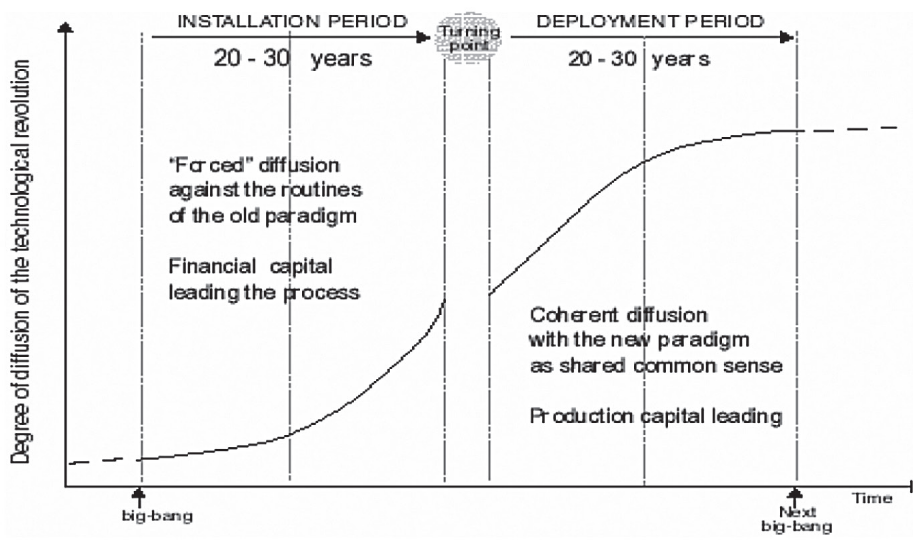

Source: Perez (2011), Fig. 2

Figure $\mathbf{2 b}$. Successive logistic waves of techno-economic paradigm shifts

Figure 3: The overlaps in the gestation, diffusion and decline of successive surges $^{30}$

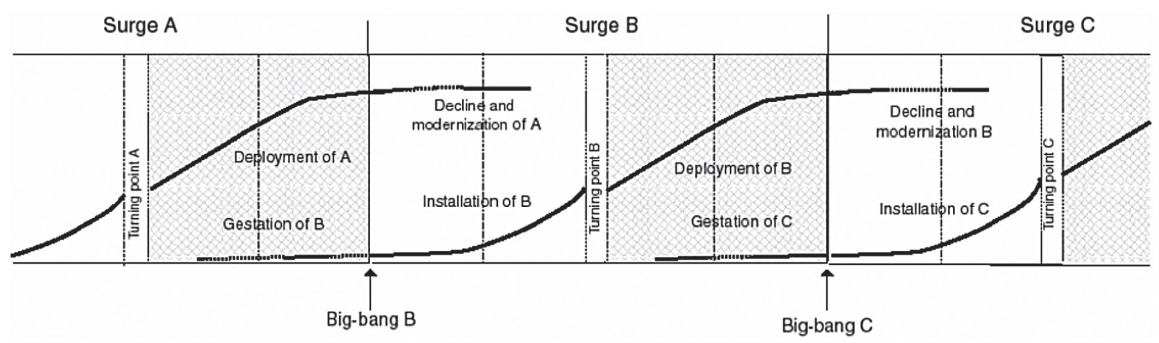

Source: Perez (2011), Fig. 3

While one technology surge is going through its deployment phase, a new one is being generated, so that there are successive logistic waves, as shown in Fig. 2b. The old technology paradigm remains stubbornly clinging to its place, through standards and the inertia of installed equipment as much as through vested interest and political obstruction (although this plays its part as well). In the case of the proposed shift to a $6^{\text {th }}$ TEP involving renewable energies, there are legal barriers as well, such as the legal protection of electric power generation monopolies found in many jurisdictions, e.g. in the US (Ayres and Ayres 2010; Sovacool 2009b). 
Perez puts the process in graphic terms: 'The irruption of a technological revolution finds an environment that is inevitably unfavourable and even hostile. It is, by definition, a breakthrough: it is the abandonment of the accepted trajectories and practice; it means the introduction of a novel way of doing things and a set of new products, industries and infrastructures that threaten the existing ones in one way or another. It is Schumpeterian creative destruction at its most visible. It will therefore elicit ferocious resistance from those that are really set for losing and from those that have not yet discovered they might benefit from it' (Perez 2011: 25).

Recall the similar argument made by Ping Chen (2008), where it is successive logistic wavelets that drives the dynamics of the economy. His argument is captured in Fig 3 (Fig. 4 in Chen 2008).

Figure 3. Successive logistic wavelets of technology surges

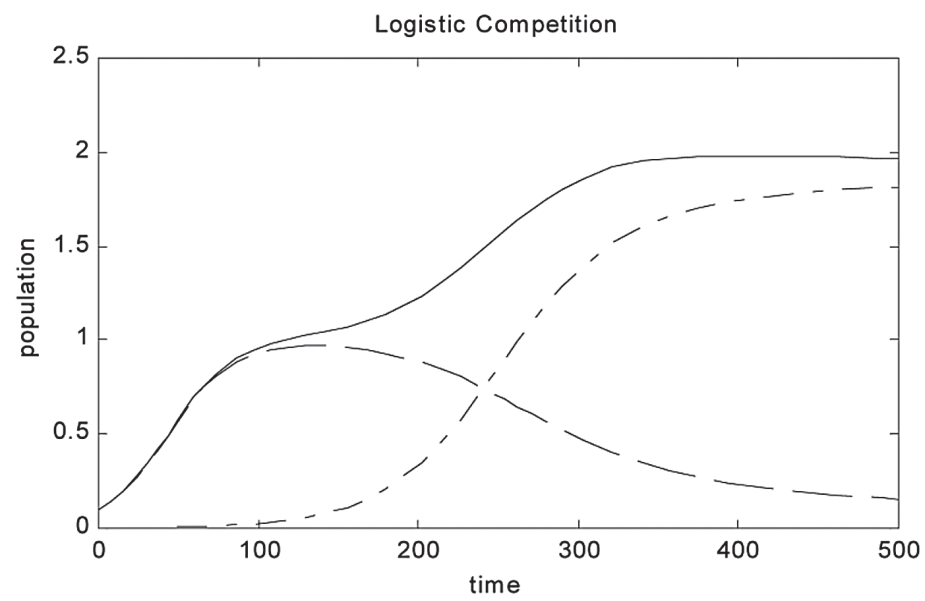

Fig. 4. The rise of new technology/industry and fall of old technology/industry under competing for imited resources and markets.

Source: Chen (2008), Fig. 4.

Now it is possible to read each of the phases in the technological eras against renewable energies to see why they do in fact constitute a 'leading factor' and hence driver of a new technology revolution, in the terms specified by Perez, Freeman, Louçã and others in the TEP tradition. But before considering this, we have to look at the role of finance.

The case of REs is both highly disruptive to the status quo energy systems but also ferociously resisted and blocked, at every level from that of costs and prices (the REs receiving minimal or negative support while 
the incumbents enjoy numerous tax advantages and subsidies) to standards and infrastructure and all the way to international environmental and sustainability treaty negotiations.

Here is where Perez sees finance playing a critical role. As she puts it, 'The new firms are too small, too weak or too inexperienced to confront the resistance of the establishment by themselves ... So the early venture capitalists are true adventurers and not mere bridges for innovation. They are in the front line of the battle against the old routines ... and in favor of the construction of an enabling environment to facilitate the diffusion of the emerging paradigm' (2011: 25).

The growing clarity of the gains to be won from the new technological surge, and its diffusion through innumerable applications not hitherto imagined, gives rise to a financing frenzy. Such bubbles are, according to Perez, always the accompaniment of a technological revolution. Its collapse signals the end of the installation period of the new paradigm. Thus the railway phase was preceded by a period of canal investment euphoria (1790s); the railways saw the railroad boom of the 1840 s which saw the end of the installation period of the second surge; the third witnessed the financial bubble in railroad stocks that ended with the panic of 1873 as well as panics in the 1890s; the fourth the financial speculation of the 'roaring twenties' that ended with the crash of 1929; and the fifth the dot.com bubble of the 1990s that ended with the crash of 2000 .

Now let us set REs into the framework of TEP shifts and the role of finance in breaking technological deadlocks.

\section{The case for REs as TEP shift}

A quick check of REs as a TEP shift reveals that it corresponds exactly to the criteria spelt out by Perez et al. On costs, the uptake of REs is driven by a learning curve (or experience curve) of drastically falling costs. The case of solar PV power generation is shown in Fig. 4, and for wind power in Fig. 5. By contrast, costs for all the fossil fuel and nuclear incumbent energy producers are rising, and can be expected to continue rising. Relative costs (which do not factor in external social costs) are still slightly favouring incumbent power producers, but it is widely expected in the energy community that grid parity is imminent, and may already be here for certain cases (onshore wind power, solar PV in well insolated locations). Let us say, conservatively, that grid parity will be achieved by 2015 - and that costs of REs will be more and more competitive after that date. That incidentally, gives us a plausible dating for the switch from a gestation phase for REs - going from the 1990s into the 2000s 
up to 2015 - and then an installation phase. Likewise in terms of fuels, biofuels in Brazil, for example, are already produced at lower cost than oil, and the propagation of such energy production is already proceeding.

The data that need to be considered in framing any development strategy are these. The most compelling evidence to note upfront is that regarding falling costs for power produced from renewable sources. The Bloomberg/New Energy Finance team in London have recently produced a White Paper on 'Re-considering the economics of photovoltaic power' (Bazilian et al 2012) where they make some very important points. Consider the chart 4 showing falling costs for solar PV over the past 35 years.

Figure 4. PV module experience curve, 1976-2011

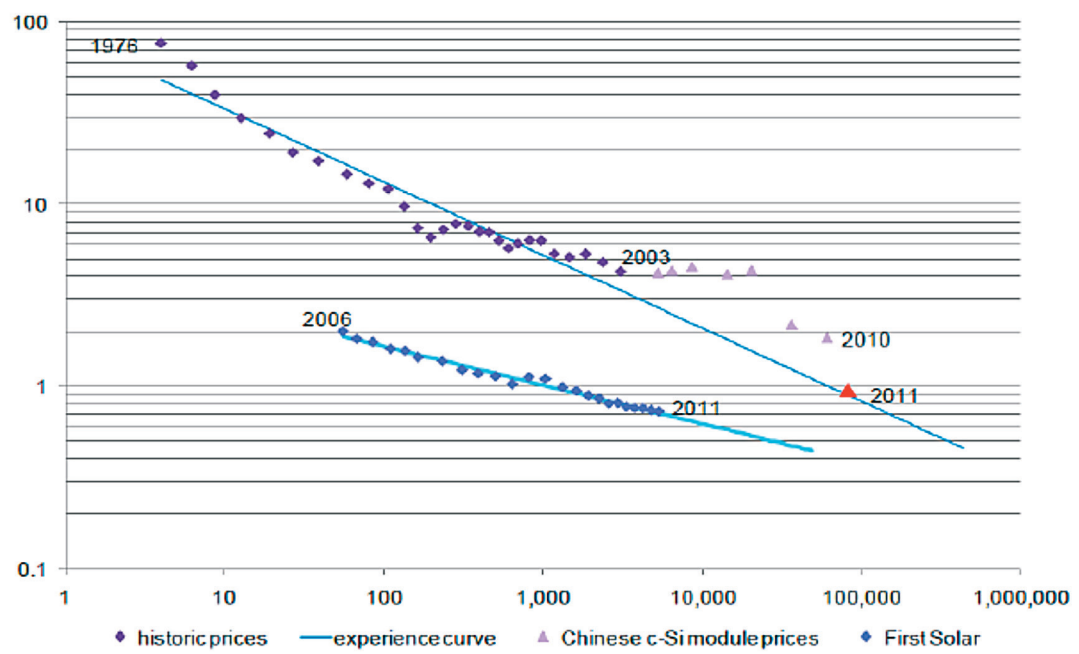

Source: BNEF Bazilian et al (2012), Fig. 1

In this chart, the overall experience curve is shown in the upper blue line, indicating that costs have been falling at an annual average rate of $45 \%$, and had reduced to the long anticipated point of $\$ 1$ per watt by the end of 2011 -- bringing solar photovoltaic (PV) power within the range of every country. But the years immediately preceding this show that costs hovered for several years (2004 to 2008) at around four times this level $(\$ 4 / \mathrm{W})$ - a phenomenon now understood to be due to suppliers being able to command feed-in tariff rates locked at these levels, while restricted silicon supplies meant that there was little price competition. It was this that led many to believe that costs of renewable energies would always exceed those of conventionally fuelled power. But as silicon supplies became more flexible, so manufacturers reduced their prices, which in turn 
reduced input costs for solar cell producers, and their prices fell as well. The bottom blue line represents the cost curve for thin-film solar cell producers, dominated by the US firm First Solar. Because TF PV cells utilize much lower quantities of silicon their costs have always been lower - but are not yet enjoying the economies of scale of amorphous silicon cells. This means that producing electric power from solar PVs is now cheaper than producing power from, e.g. stand-alone diesel generators.

Wind energy as well exhibits powerful learning curve advantages, with costs declining for onshore wind at the rate of $7 \%$. The experience curve for wind is shown in Fig. 5.

Figure 5. Wind costs decline, 1984-2011

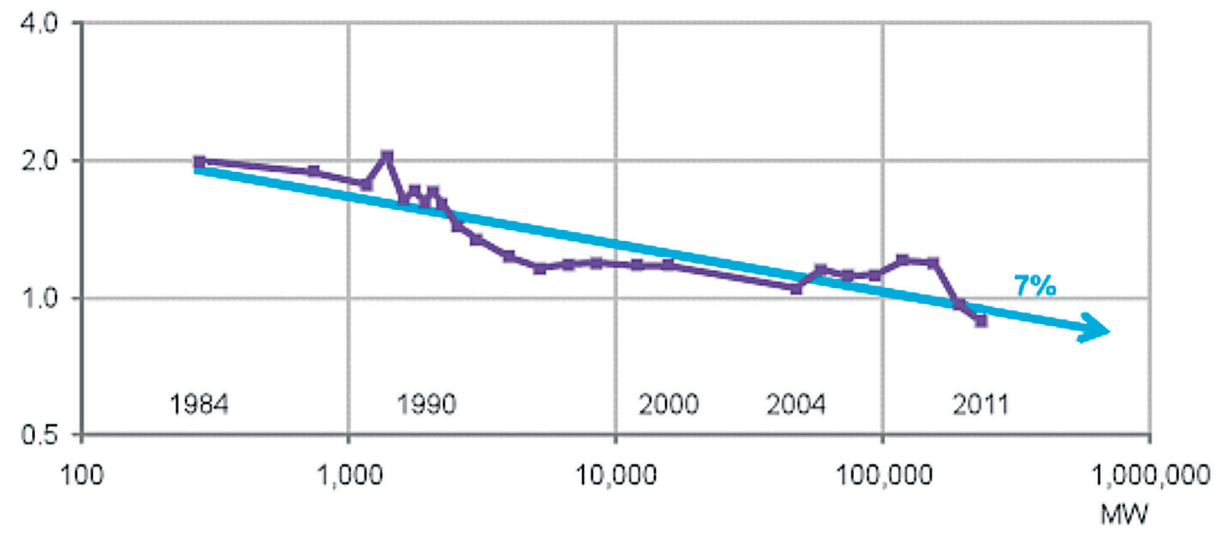

Note: Learning curve (blue line) is least square regression: $\mathrm{R} 2=0.77$ and $7 \%$ learning rate.

Source: Bloomberg NEF

On the generation of entrepreneurial opportunities, the REs paradigm is already well advanced. The entrepreneurial and business openings are being created in the immediate sector of RE generation systems themselves (wind power generators, solar PV generators, concentrated solar power towers and linear arrays) and the supply chains that are created to feed these new end-products; and then in associated business activities that utilize renewable energies as priority, such as electric vehicle charging systems in cities; and finally in the range of totally new activities associated with REs such as new and smart grids, new metering systems, new transport systems such as EVs and their associated infrastructure (charging systems), new industrial heating systems utilizing concentrated solar power - and so on. In the case of each new paradigm, Perez sees the evolution and interaction between productive and finance capital as follows: 'the world of finance itself is amongst the pioneers in adopting 
the new paradigm, especially in organisation, equipment, transport and communications. It rapidly invents, learns and diffuses new ways of providing venture capital, of attracting new investors and new capital to the market and of leveraging, handling, hedging and spreading risk' (2009: 781). Specifically in the case of REs and low-carbon technologies in the 2010s, we see the role of finance for example in inventing new eco-targeted bonds (green bonds, or climate bonds) which can be expected to attract major institutional investors and to aggregate projects to the scale of index-oriented investment (Mathews and Kidney 2010; 2012)."

Thirdly, on the systemic character of the change, where, as Perez (2010) puts it, 'practice keeps showing the superior performance of particular methods and structures when it comes to taking advantage of the power of the new technologies for maximum efficiency and profits'. This superior systemic performance in the case of the fourth TEP was shown by mass production industries, organized on new Taylorist principles of the division of labour, and eventually in new divisionalized corporations, which overwhelmed their earlier rivals; and in the fifth TEP, these organizational forms and principles were in turn overwhelmed by the new network and flexible structures that meshed easily with new modes of governance utilizing IT and ICT, such as CAD/CAM and FMS. Now in the case of REs we have an equivalent consideration in the meshing of biomimetic, modular organizational patterns (principles) with decentralized generation of power from dispersed renewable energy sources and a swing away from the equation of energy efficiency with increasing centralization of generation operations, and instead a new focus on resilience associated with dispersed power generating from a near-universal supply of renewable energy inputs (Mathews 2011b; 2012b). Major innovations such as generation of solar power in deserts utilizing Concentrated Solar technology (e.g. linking generation systems in North Africa to European power companies, as proposed in the Desertec project (Battaglini et al 2009)) and the upgrading of power grids with IT, promise as many associated investment opportunities as there are entrepreneurs to find them.

To round out this picture, I need to specify some of the 'organizing principles' of this emergent sixth TEP - ones which favour the emergence of $\mathrm{RE}$ systems and which clash with those developed during the previous fourth and fifth TEPs. Amongst these emerging energetic 'commonsense' principles we would have to include:

\footnotetext{
10 See the report issued by Climate Bonds Initiative and HSBC Climate Change Centre of Excellence, where the size of the market for bonds that underpin expansion of the green economy is estimated as amounting to $\$ 174$ billion currently, in early 2012 , with enormous potential for growth beyond this. The report is available at: http://climatebonds.net/2012/05/hsbc-climatebonds-report/
} 
- Decentralized generation of power, from multiple renewable sources;

- Competitive reduced energy intensity and enhanced efficiency, through operations of energy services companies;

- Intelligent (smart) IT-enabled grids for distribution of renewable electric power;

- Biomimetic organizational and industrial design principles;

- Circulation of resources: circular economy;

- Linked heat and power with resource recirculation; and

- Eco-targeted finance.

\section{The role of finance}

Returning to the role of finance, in the case of REs we can expect finance to play the role envisaged by Perez in her comprehensive TEP framework. If the last decade has seen REs emerging from out of their long (prolonged) gestation phase and into the installation phase, then we can anticipate a 'Renewable Energy bubble' some time perhaps around 2015 to 2020, reflecting the surge of financing and credit creation into the field of REs and green technologies, with again China leading the way."

Interestingly enough, it is precisely the dating of a new surge in RE investment from around $2011 / 2012$ to around 2020 that is identified by the Russian scholars, Korotayev and Tsirel - and which could be the very mechanism that brings about a 'Renewable energy financial bubble' within the next decade.

\section{The case for REs as a secondary technology surge at the turn of the $5^{\text {th }}$ upswing}

We began with a discussion of the long waves of industrial capitalism, situating the current transition to green economy and renewable energy

\footnotetext{
11 On the role of resource recirculation and the circular economy, with specific reference to China, see Mathews and Tan (2011).

12 This leaves the GFC of 2008/09 out of account. It is difficult to see the GFC as linked to any specific technological surge - although some have argued that it was triggered by the oil price spike of $2007 / 08$. Of course the argument surrounding successive TEP shifts does not seek to account for every financial crash, nor indeed for the clear industry cycles involving specific technologies such as semiconductors, flat panel displays and perhaps, now, solar PV cells as well. These industry cycles operate with periods of three to five years, and are treated by most informed observers as instances of Kitchin cycles.
} 
initiatives in a longer historical setting, as the latest in a series of such industrial upheavals and transformations. But the question remains: is there a new 'long wave' in the making, driven by investments in renewable energy?

To seek an answer to this question, we turn to the work of Andrey Korotayev, discussed above. As a result of the spectral analysis of long waves conducted with his collaborator Sergey Tsirel, Korotayev analyses the current situation (as of 2011) as moving in one of two different directions. The background to this analysis is provided by spectral analysis of the third, fourth and fifth waves, as shown in Fig. 6 below.

Fig. 6. K-wave pattern revealed by spectral analysis, 1870-2010

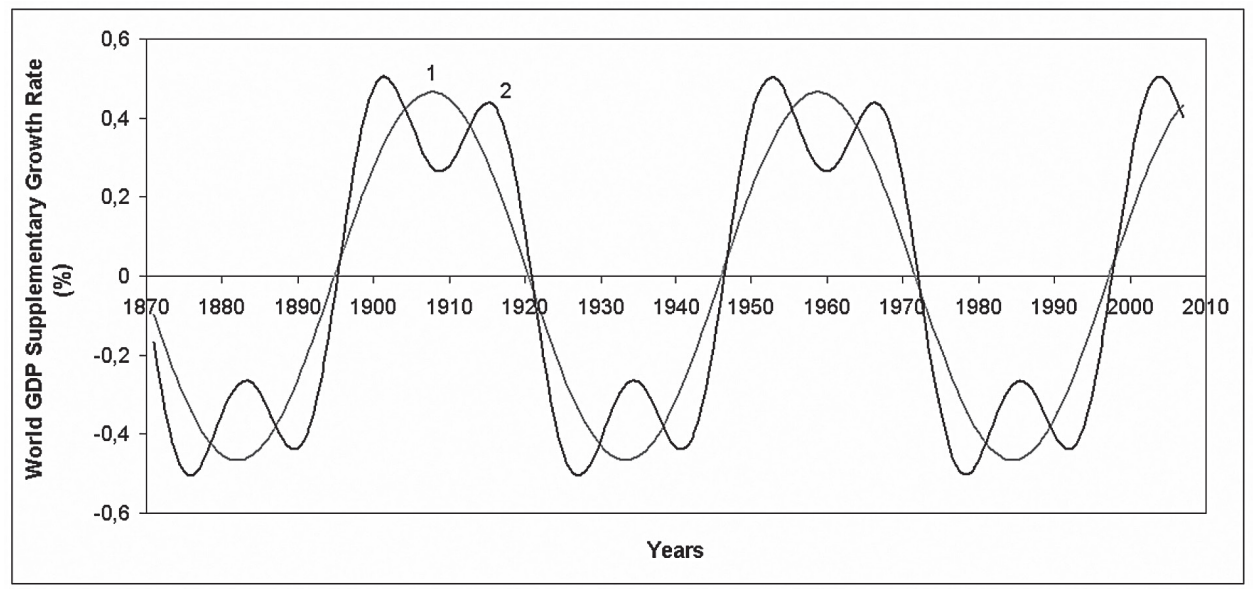

Source: Korotayev and Tsirel (2010), Fig. 3-A, showing the first harmonic (wave 1) and the sum of the first and third harmonics (curve 2) with the world war and interwar values replaced by geometric means.

The Russian scholars interpret their reconstruction of the long waves, utilizing their spectral analysis, as revealing a strikingly consistent longwave pattern, with a shortening of the wave period closer to the present time. The current period, which looks like the peaking of the fifth K-wave, could indeed be such - and the global financial crisis of 2008-09 would be taken from this reading as the signal for the downturn. But the authors also offer an alternative and most intriguing reading - namely that the current period may be interpreted as a temporary depression between two peaks of the upswing. By extrapolation, they predict that such a temporary upswing may begin around 2011-2012 (i.e. now) and reach its maximum by 2018-2020. The source of such a temporary upswing is left unsaid in their paper. They discount the role of communications and IT, which is thought to have exhausted its reserves of fast growth. One fac- 
tor that they do point to is the acceleration of convergence (of East on West) through 'acceleration of the diffusion of the extant high technologies to the populous countries of the World System periphery' - of which China would have to be taken as prime exemplar, and in which green technologies would have to be identified as prime candidates. While expressing the appropriate caution, this does in fact seem to be the authors' implied candidate. However there is also strong evidence that the more obvious interpretation, that world GDP has just gone through its $\mathrm{K}$-wave peak, is also plausible - particularly if the world falls into a 'double dip' recession in 2011-12. The authors conclude: 'At the moment it does not seem to be possible to decide finally which of those two interpretations is true..$^{13}$

There are both theoretical and practical implications of this statement. Practically, it provides a strong justification for governments spending what is needed to avoid a double-dip recession, thus opening up for China, India et al the possibility of creating a 'short upswing' driven by investments in renewables and low-carbon technologies. This is not the time to take a disinterested stance, declaring that 'the market' will fix it. Theoretically, in terms of the Perez-Freeman TEP framework, this 'secondary surge' may be identified with the emergence of the next TEP (based on REs) moving from its gestation to installation phase within the matrix of the current paradigm.

\section{The case for REs as a third energy-industrial revolution}

There is also a case for examining the energy sector as sui generis - as one characterized by long-gestating systemic changes and successive industrial revolutions. And it is also one where the institutional barriers and impediments to systemic change placed deliberately and as part of systemic inertia, are most clearly in evidence. There is, for example, widespread agreement that the Industrial Revolution was actually a revolution in energy source, with water and wind and muscle power being replaced by coal as fuel for industrial heating (e.g. to produce iron or glass) and to generate steam. This first energy-revolution was then followed by electrification, which counts as a second energy industrial revolution; and then there is the current shift to energy efficiency and renewables, which constitutes a third.

The polymath author Jeremy Rifkin adopts such a stance in his concept of the 'third industrial revolution' based on renewable energies. In Rifkin

13 See Korotayev and Tsirel (2010): 19-21. 
(2012) he identifies what he calls 'five pillars' of this next industrial revolution, specifically: 1) a shift to renewable energies; 2) converting buildings into power plants (e.g. by solar panels); 3) introduction of hydrogen and other energy storage technologies; 4) smart grid technology (internetbased); and 5) plug-in, electric, hybrid and fuel cell transportation.

Such a perspective is supported by the emerging literature regarding renewables as providing an anticipated $100 \%$ replacement for fossil fuels within a reasonably short time frame, such as by around 2030 (e.g. Jacobson and Delucchi 2011; Scheer 2010). Rifkin's 'five pillars' are undoubtedly fundamental features of the current shift. Ayres and Ayres (2010) add the essential element of a shift to energy-efficient and energysaving innovations as an equally important feature of this fundamental transformation."

I suggest that these contributions underline the significance of the current shift that is under way to renewables and low-carbon energy systems and technologies. They focus on contingent features of the renewable energies technology 'surge' and do not add theoretical depth to the notion of TEP already formulated by neo-Schumpeterian scholars (but not applied by them to fundamental energy transformations). The more systemic our perspective, the more that institutional barriers loom as serious impediments to change.

\section{Discussion: Policy implications and likely trajectories}

We have then three different ways of characterizing the surge in renewable energy technologies that is currently under way, informed by technological and industrial revolutionary perspectives. There is the TEP perspective of Freeman and Perez, which is transformed by Perez herself into an abstract four-phase formulation of techno-economic shifts involving periodic technology surges and financial bubbles. There is the long K-waves perspective of Korotayev and Tsirel, with its clear dating and cyclic patterns, that admit of very clear identification of relevant technology surges. And there is the 'third industrial revolution' perspective which reinforces, in a general and contingent way, the transformation currently under way from fossil-fuelled energy systems to renewables. How to reconcile these views?

\footnotetext{
14 The role of renewable energies and greening of technology systems generally is emphasized in other streams of work, such as Ecological Modernization Theory (e.g. Mol and Sonnenfeld 2000), sustainability-oriented innovation systems (Altenburg and Pegels 2012) and in the greening of economic geography (e.g. Hayter 2008). As in the case of the 'third energy-industrial revolution' these perspectives seem to support the notion of an emergent $6^{\text {th }}$ TEP without adding anything fundamental to the argument.
} 
The issue of dating turns out to be critical. ' $\mathrm{F} \& \mathrm{P}^{\prime}$ of the 1980 s and into the 1990s sought to reconcile a five-fold TEP-framework with Kondratiev-Schumpeterian long waves as identified in the literature, offering a convincing account of prior technology revolutions and particularly of the upheavals under way coincident with the rise of microelectronics, integrated circuits, IT and ICT generally. However in Perez (2002) and onwards this quest for historical fidelity in terms of long waves is abandoned, and instead an abstract schema of four-phase TEPs is offered, involving both productive and financial capital. The insights are profound, but they are achieved at the cost of being linked to datable real-world events. Then K\&T enter the picture, and return to the basic economic data of GDP fluctuations (as smoothed and subjected to spectral analysis), and generate historical and contemporary patterns that cry out for some explanation in Schumpeterian terms, as driven by clusters of innovations. Both approaches are supported by the general literature on current energy system transformations.

My suggestion is the following. The current surge in renewable energy investments and capacity additions is real and is having real socio-technoeconomic effects. It is the harbinger of a sixth TEP, with REs as driving factor, where we see the new RE-driven TEP emerging from its gestation phase and entering the installation phase, where finance capital is more daring than productive capital. If Perez is correct in her formulations, we can expect this RE paradigm to blow out into a speculative financial bubble, that might be dated (according to previous sequencing) sometime in the period 2015-2020. That gives several more years of booming RE investments, with RE systems moving along a logistic industrial trajectory to become, by the time of the bursting of the bubble, the new 'conventional wisdom' in energy generation. This would pave the way to a true 'deployment' phase of renewable energies and energy-service innovations, driven by productive capital. Such a perspective corresponds almost exactly to the findings of K\&T in identifying a 'secondary surge' in investment at the turn of the fifth K-wave, which they date from around $2011 / 12$ to the period around 2020 . This is a remarkable coincidence of neo-Schumpeterian scholarly views, albeit starting from quite different premises.

Moreover, the emergence of this $6^{\text {th }}$ TEP is seen not to be in conflict with the $5^{\text {th }}$ TEP based on IT and ICT but instead as a continuation and fulfilment of it. Indeed one might argue that it is only when IT and ICT come to be applied to the electric power grid, to electric vehicles, and to the generation and consumption of renewable energy, that the $5^{\text {th }}$ TEP can really be said to be in its full deployment phase; until it is so applied its effects must be constrained. By contrast, the emergent $6^{\text {th }}$ TEP based on 
REs is really in fundamental conflict with the incumbent and obstructive $4^{\text {th }}$ TEP based on fossil fuels (oil, gas, coal) and centralized electric power generation. It is the elements of the $4^{\text {th }}$ TEP that are retarding not just the full emergence of the $5^{\text {th }}$ TEP but especially the $6^{\text {th }}$ TEP, and in this sense they can be seen to be allied against the continuing features of the fossil-fuelled and centralized power generation paradigm. This is an important qualification that reinforces the case that the emergent $6^{\text {th }}$ TEP may be recognized in the 'secondary surge' at the turn of the $5^{\text {th }}$ TEP, as argued by Korotayev and Tsirel - and therefore as an extension and continuation of the $5^{\text {th }}$ TEP, not as its opponent.

What is interesting is that whatever the perspective taken - a sixth TEP shift, or a resurgence at the turn of the $5^{\text {th }}$ TEP, or a third energy-industrial revolution - the policy implications are all more or less the same. What is needed to accomplish the shift is policy directed towards dismantling the institutional supports of the incumbent regime, and building fresh institutional and systemic supports for the new. Policies to build and extend the market for the emerging RE systems are clearly what are called for, in order to oppose and neutralize the 'ferocious' resistance by incumbents. Policies as weak as carbon taxes can be expected to provide minimal influence, whereas policies of targeted public procurement and military procurement (being developed for example by the US Armed Forces), together with market mandates (e.g. specifying that certain proportions of energy markets must be met by renewables) can be expected to have greater influence. On the consumer side, policies like feed-in tariffs have proven to be powerful shapers of RE uptake and decentralization of the energy generation system, in line with the overall technical trend and potential of the new paradigm (Scheer 2010; Sovacool 2009a). And in the case of deployment of renewables and decentralizing power generation systems (both to admit renewables and energy-saving innovations, such as combined heat and power) there can be not just political and economic obstacles but legal impediments as well, such as the protection of monopoly privileges awarded early in the $20^{\text {th }}$ century to power generators in many jurisdictions (Ayres and Ayres 2010). By contrast, calls by economists and public intellectuals simply for 'more $R \& D$ ' as a way of moving away from 'Business as Usual' in response to global warming, are seen to be lame indeed.

The trajectory for the REs paradigm in the coming decades is likely to be one of total replacement of conventional (fossil fuelled and nuclear) power sources by those based on decentralized generation and distribution of renewable sources. But equally the new TEP (or energy industrial revolution) may be frustrated and blocked by powerful forces of industrial inertia and 'carbon lock-in' (Unruh 2000). The future, of course, is far from determined. 
China is in fact emerging as the dominant force in the RE technology surge, or TEP shift, dominating investment in specific technologies such as solar PV, wind and passive solar heating, but also and more importantly, in infrastructure. Take the case of charging points for EVs - where China dominates the build-up of both AC charging points as well as the newest 'fast charging' points using DC power (Fig. 7). This is infrastructure development that is specific to the emergent $6^{\text {th }}$ TEP, creating entrepreneurial and financial opportunities that cannot be obstructed by incumbent and vested interests, and creating new platforms for export-oriented industries of tomorrow - as part of emergent 'green growth' strategies (Mathews 2011a; 2012a)

Figure 7. EV charging points deployment: $A C$ and fast (DC): China dominates

Figure 7: Public EV charging point deployment (AC), 2009-13e (Units)

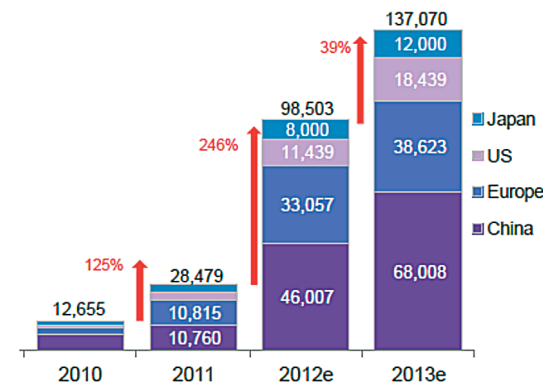

Figure 8: Public EV fast charging point deployment (DC), 2009-13e (Units)

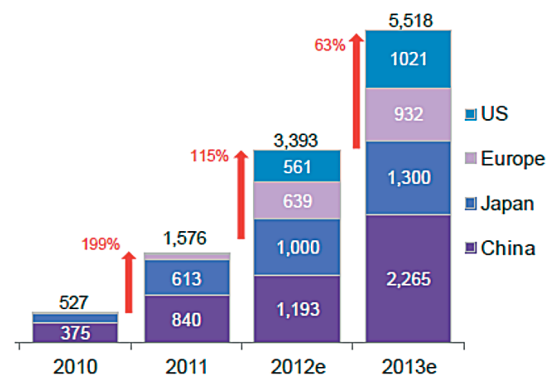

Source: Bloomberg New Energy Finance. Note: For ease of display, Israel is here included in Europe.

China is in fact emerging as the dominant country in acting on and bringing into fruition the new era based on REs - at the same time as it is expanding its 'black' fossil-fuelled power, industrial and transport systems. It is a race against time which trajectory will emerge triumphant - but influential scholars like Hu (2006; 2011) see the greening of its economy as the 'inevitable choice for China' - given that the costs to China (and the world) of proceeding exclusively along the Business as Usual path would be devastating.

The biggest question is: can the new RE paradigm be introduced in time in order to decarbonize the world's (and China's) energy systems and wider industrial system? The urgency of the situation calls for an acceleration of the diffusion of REs and their replacement of existing fossil fuelled and nuclear power systems. But the institutional opposition and inertia of vested interests (indeed the non-creative obstruction demonstrated by vested interests, as opposed to Schumpeter's creative destruction) slows down the diffusion. The insights generated by previous shifts 
in TEP, in particular the five such shifts recorded since the industrial revolution, clearly offer some guidance as to the way forward.

The neo-Schumpeterian TEP framework provided by Perez and Freeman, based on Kondratiev and added to significantly by Korotayev and Tsirel, provides (I would suggest) currently the soundest framework for understanding the current surge in renewable energy investment, and building on it to create a genuine defence against the ravages of global warming. There is nothing more important in the current period than the greening of energy systems and of technology generally, to pave the way to a clean energy future modelled on biomimetic and ecologically sustainable lines. Nothing could be more important for the future of our industrial civilization.

\section{References}

Altenburg, T. and Pegels, A. 2012. Sustainability-oriented innovation systems: Managing the green transformation, Innovation and Development, 2 (1): 5-22.

Ayres, R.U. 1989. Technological transformations and long waves. Working paper RR-89-1. Laxenburg, Austria: IIASA.

Ayres, R.U. 2001. Industrial ecology: Wealth, depreciation and waste. In H. Folmer, H.L. Gabel an S. Gerking (eds), Frontiers of Environmental Economics. Cheltenham, UK: Edward Elgar.

Ayres, R.U. and Ayres, E.H. 2010. Crossing the Energy Divide: Moving from Fossil Fuel Dependence to a Clean Energy Future. Upper Saddle River, NJ: Wharton School Publishing.

Battaglini, A., Lilliestam, J., Haas, A. and Patt, A. 2009. Development of SuperSmart grids for a more efficient utilisation of electricity from renewable sources, Journal of Cleaner Production, 17 (10): 911918.

Bazilian, M., Onyeji, I., Liebreich, M., MacGill, I., Chase, J., Shah, J., Gielen, D., Arent, D., Landfear, D. And Zhengrong, S. 2012. Reconsidering the economics of photovoltaic power, White Paper \#82, Bloomberg New Energy Finance, London. Available at: http:// www.bnef.com/WhitePapers/download/82

Chen, P. 2008. Equilibrium illusion, economic complexity and evolutionary foundation in economic analysis, Evolutionary and Institutional Economics Review, 5 (1): 81-127.

Drechsler, W., Kattel, R. and Reinert, E. 2009. Techno-Economic Paradigms: Essays in Honour of Carlota Perez. Anthem Press/The Other Canon.

Freeman, C. (ed) 1983. Long Waves in the World Economy. London: Butterworth. 
Freeman, C. (ed) 1986. Design, Innovation and Long Cycles in Economic Development. London: Frances Pinter.

Freeman, C. 1989. New technology and catching up, European Journal of Development Research, 1 (1): 85-99.

Freeman, C. 1991. Innovation, changes in techno-economic paradigm and biological analogies in economics, Revue Economique, 42 (2): 211-231.

Freeman, C. 1996. The greening of technology and models of innovation, Technological Forecasting and Social Change, 53 (1): 27-39.

Freeman, C. 1997. Schumpeter's Business Cycles and techno-economic paradigms, Science Policy Research Unit. Available at: http://dcsh. xoc.uam.mx/eii/globelicswp/SCHUMPETERS_BUSINESS_ CYCLES_REVISITED.pdf

Freeman, C. and Louçã, F. 2001. As Time Goes By: From the Industrial Revolutions to the Information Revolution. Oxford: Oxford University Press.

Freeman, C. and Perez, C. 1988. Structural crises of adjustment : Business cycles and investment behaviour. In G. Dosi et al (eds), Technical Change and Economic Theory. London: Frances Pinter.

Hayter, R. 2008. Environmental economic geography, Geography Compass, 2/3: 831-850.

Hu, A. 2006a. Green development: The inevitable choice for China (Part 1), China Dialogue, available at: http://www.chinadialogue.net/ article/show/single/en/134

Hu, A. 2006b. Green development: The inevitable choice for China (Part 2), China Dialogue, available at: http://www.chinadialogue.net/ article/show/single/en/135-Green-development-the-inevitablechoice-for-China-part-two-

Hu, A. 2011. China in 2020: A New Type of Superpower. Washington, DC: Brookings Institution.

Jacobson, M.Z. and Delucchi, M.A. 2011. Providing all global energy with wind, water and solar power. Part I: Technologies, energy resources, quantities and areas of infrastructure, and materials, Energy Policy, 39 (3): 1154-1169.

Kondratiev, N. 1935. The long waves in economic life, Review of Economic Statistics, 17 (Nov): 1065-115.

Korotayev, A.V. and Tsirel, S.V. 2010. A spectral analysis of world GDP dynamics: Kondratieff waves, Kuznets swings, Juglar and Kitchin cycles in global economic development, and the 2008-2009 economic crisis, Structure and Dynamics, 4 (1), e-journal, located at: http://escholarship.org/uc/item/9jv108xp

Louçã, F. 1997. Turbulence in Economics. Cheltenham: Elgar.

Mathews, J.A. 1989. New production concepts, Prometheus, 7 (1): 129-148. 
Mathews, J.A. 2008. Energizing industrial development, Transnational Corporations, 17 (3): 59-84.

Mathews, J.A. 2011a. Naturalizing capitalism: The next Great Transformation, Futures, 43: 868-879.

Mathews, J.A. 2011b. Designing energy industries for the next industrial revolution. Organizational Dynamics, 39 (2): 155-164.

Mathews, J.A. 2011c. China's energy industrial revolution, I'Industria, 32 (2): 309-328.

Mathews, J.A. 2012a. Green growth strategies: Korea's initiatives, Futures, 44: 761-769.

Mathews, J.A. 2012b. Design of industrial organizational architectures: Economic growth and sustainability, Journal of Organizational Design (forthcoming).

Mathews, J.A. and Kidney, S. 2010. Climate bonds: Mobilizing private financing for carbon management, Carbon Management, 1 (1): 9-13.

Mathews, J.A. and Kidney, S. 2012. Debate: Financing climate-friendly energy development through bonds, Development Southern Africa, 29 (2): 337-349.

Mathews, J.A. and Tan, H. 2011. Progress towards a Circular Economy in China: Drivers (and inhibitors) of eco-industrial initiative, Journal of Industrial Ecology: 15 (3): 435-457.

Mathews, J.A., Hu, M.-C. and Wu, C.-W. 2011. Fast-follower industrial dynamics: The case of Taiwan's Solar PV industry, Industry and Innovation, 18 (2): 177-202.

Mol, P.J. and Sonnenfeld, D.A. 2000. Ecological modernisation around the world: An introduction, Environmental Politics, 9 (1): 1-14.

Perez, C. 1983. Structural change and assimilation of new technologies in the economic and social systems, Futures, 1983 (10): 357-375.

Perez, C. 1985. Microelectronics, long waves and world structural change: New perspectives for developing countries, World Development, 13 (3): 441-463.

Perez, C, 1992. New technological model and higher education: A view from the changing world of work. In G. Lopez Ospina (ed), Challenges and Options: Specific Proposals. Caracas: UNESCO.

Perez, C. 2001. Technological change and opportunities for development as a moving target, Cepal Review, 75 (Dec): 109-130.

Perez, C. 2002. Technological Revolutions and Financial Capital: The Dynamics of Bubbles and Golden Ages. Cheltenham, UK: Edward Elgar.

Perez, C. 2004. Technological revolutions, paradigm shifts and socioinstitutional change. In E. Reinert (ed), Globalization, Economic Development and Inequality: An Alternative Perspective. Cheltenham, UK: Edward Elgar. 
Perez, C. 2007. Finance and technical change: A long-term view. In H. Hanusch and A. Pyka (eds), Elgar Companion to Neo-Schumpeterian Economics. Cheltenham, UK: Edward Elgar.

Perez, C. 2009. The double bubble at the turn of the century: Technological roots and structural implications, Cambridge Journal of Economics, 33: 779-805.

Perez, C. 2010. Technological revolutions and techno-economic paradigms, Cambridge Journal of Economics, 34: 185-202.

Perez, C. 2011. Finance and technical change: A long-term view, African Journal of Science, Technology, Innovation and Development, 3 (1): 10-35.

Perez, C. 2012. Innovation systems and policy: Not only for the rich? Working Papers in Technology, Governance and Economic Dynamics No. 42. Norway: The Other Canon Foundation.

Perez, C. and Soete, L. 1988. Catching up in technology: Entry barriers and windows of opportunity. In G. Dosi, C. Freeman, R. R. Nelson, G. Silverberg, \& L. Soete (Eds.), Technical Change and Economic Theory. London: Pinter.

Rifkin, J. 2011. The Third Industrial Revolution: How Lateral Power is Transforming Energy, the Economy, and the World. London: Palgrave-Macmillan.

Scheer, H. 2007. Energy Autonomy: The Economic, Social and Technical Case for Renewable Energy. London: Earthscan (Routledge).

Scheer, H. 2012. The Energy Imperative: 100 Percent Renewable Now. London: Earthscan (Routledge).

Schumpeter, J. A. 1911 (1934; 1961), The Theory of Economic Development, New York: Oxford University Press.

Schumpeter, J. A. 1939 (1982), Business Cycles, 2 vols., Philadelphia: Porcupine Press.

Sovacool, B. 2009a. The importance of comprehensiveness in renewable electricity and energy-efficiency policy, Energy Policy, 37 (4): $1529-1541$.

Sovacool, B. 2009b. Rejecting renewables: The socio-technical impediments to renewable electricity in the United States, Energy Policy, 37 (11): 4500-4513.

Tylecote, A. 1992. The Long Wave in the World Economy: The Present Crisis in Historical Perspective. London: Routledge.

Unruh, G. 2000. Understanding carbon lock-in, Energy Policy, 28: 817-830.

Unruh, G. and del Rio, P. 2012. Unlocking the unsustainable technoinstitutional complex. In G. Marletto (ed), Creating a Sustainable Economy: An Institutional and Evolutionary Approach to Environmental Policy. London: Routledge.

Van Duijn, J.J. 1977. The long wave in economic life, De Economist, 125 (4): 544-576. 


\section{Working Papers in Technology Governance and Economic Dynamics}

The Other Canon Foundation, Norway, and the Technology Governance program at Tallinn University of Technology (TUT), Estonia, have launched a new working papers series, entitled "Working Papers in Technology Governance and Economic Dynamics". In the context denoted by the title series, it will publish original research papers, both practical and theoretical, both narrative and analytical, in the area denoted by such concepts as uneven economic growth, techno-economic paradigms, the history and theory of economic policy, innovation strategies, and the public management of innovation, but also generally in the wider fields of industrial policy, development, technology, institutions, finance, public policy, and economic and financial history and theory.

The idea is to offer a venue for quickly presenting interesting papers scholarly articles, especially as preprints, lectures, essays in a form that may be developed further later on - in a high-quality, nicely formatted version, free of charge: all working papers are downloadable for free from http://hum.ttu.ee/tg as soon as they appear, and you may also order a free subscription by e-mail attachment directly from the same website.

The working papers published so far are:

1. Erik S. Reinert, Evolutionary Economics, Classical Development Economics, and the History of Economic Policy: A Plea for Theorizing by Inclusion.

2. Richard R. Nelson, Economic Development from the Perspective of Evolutionary Economic Theory.

3. Erik S. Reinert, Development and Social Goals: Balancing Aid and Development to Prevent 'Welfare Colonialism'.

4. Jan Kregel and Leonardo Burlamaqui, Finance, Competition, Instability, and Development Microfoundations and Financial Scaffolding of the Economy.

5. Erik S. Reinert, European Integration, Innovations and Uneven Economic Growth: Challenges and Problems of EU 2005.

6. Leonardo Burlamaqui, How Should Competition Policies and Intellectual Property Issues Interact in a Globalised World? A Schumpeterian Perspective

7. Paolo Crestanello and Giuseppe Tattara, Connections and Competences in the Governance of the Value Chain. How Industrial Countries Keep their Competitive Power

8. Sophus A. Reinert, Darwin and the Body Politic: Schäffle, Veblen, and the Shift of Biological Metaphor in Economics

9. Antonio Serra, Breve Trattato / A Short Treatise (1613) (available only in hardcopy and by request). 
10. Joseph L. Love, The Latin American Contribution to CenterPeriphery Perspectives: History and Prospect

11. Ronald Dore, Shareholder capitalism comes to Japan

12. Per Högselius, Learning to Destroy. Case studies of creative destruction management in the new Europe

13. Gabriel Yoguel, Analía Erbes, Verónica Robert and José Borello, Diffusion and appropriation of knowledge in different organizational structures

14. Erik S. Reinert and Rainer Kattel, European Eastern Enlargement as Europe's Attempted Economic Suicide?

15. Carlota Perez, Great Surges of development and alternative forms of globalization

16. Erik S. Reinert, lulie Aslaksen, Inger Marie G. Eira, Svein Mathiesen, Hugo Reinert \& Ellen Inga Turi, Adapting to Climate Change in Reindeer Herding: The Nation-State as Problem and Solution

17. Lawrence King, Patrick Hamm, The Governance Grenade: Mass Privatization, State Capacity and Economic Development in Postcommunist and Reforming Communist Societies

18. Reinert, Erik S., Yves Ekoué Amaïzo and Rainer Kattel, The Economics of Failed, Failing and Fragile States: Productive Structure as the Missing Link

19. Carlota Perez, The New Technologies: An Integrated View

20. Carlota Perez, Technological revolutions and techno-economic paradigms

21. Rainer Kattel, Jan A. Kregel, Erik S. Reinert, The Relevance of Ragnar Nurkse and Classical Development Economics

22. Erik S. Reinert, Financial Crises, Persistent Poverty, and the Terrible Simplifiers in Economics: A Turning Point Towards a New "1848 Moment"

23. Rainer Kattel, Erik S. Reinert and Margit Suurna, Industrial Restructuring and Innovation Policy in Central and Eastern Europe since 1990

24. Erkki Karo and Rainer Kattel, The Copying Paradox: Why Converging Policies but Diverging Capacities for Development in Eastern European Innovation Systems?

25. Erik S. Reinert, Emulation versus Comparative Advantage: Competing and Complementary Principles in the History of Economic Policy

26. Erik S. Reinert, Capitalist Dynamics: A Technical Note

27. Martin Doornbos, Failing States or Failing Models?: Accounting for the Incidence of State Collapse

28. Carlota Perez, The financial crisis and the future of innovation: A view of technical change with the aid of history 
29. Rainer Kattel and Annalisa Primi, The periphery paradox in innovation policy: Latin America and Eastern Europe Compared

30. Erkki Karo and Rainer Kattel, Is 'Open Innovation' Re-Inventing Innovation Policy for Catching-up Economies?

31. Rainer Kattel and Veiko Lember, Public procurement as an industrial policy tool - an option for developing countries?

32. Erik S. Reinert and Rainer Kattel, Modernizing Russia: Round III. Russia and the other BRIC countries: forging ahead, catching up or falling behind?

33. Erkki Karo and Rainer Kattel, Coordination of innovation policy in the catching-up context: Estonia and Brazil compared

34. Erik S. Reinert, Developmentalism

35. Fred Block and Matthew R. Keller, Where do Innovations Come From? Transformations in the U.S. Economy, 1970-2006

36. Erik S. Reinert \& Arno Mong Daastøl, Production Capitalism vs. Financial Capitalism - Symbiosis and Parasitism. An Evolutionary Perspective and Bibliography

37. Erik S. Reinert, Zeitgeist in Transition: An Update to How rich countries got rich...and why poor countries stay poor

38. Marek Tiits \& Tarmo Kalvet, Nordic small countries in the global high-tech value chains: the case of telecommunications systems production in Estonia

39. Erik S. Reinert, Mechanisms of Financial Crises in Growth and Collapse: Hammurabi, Schumpeter, Perez, and Minsky

40. Erik S. Reinert, Economics and the Public Sphere

41. Osvaldo Urzúa, Emergence and Development of KnowledgeIntensive Mining Services (KIMS)

42. Carlota Perez, Innovation systems and policy: not only for the rich?

43. Peer Vries, Does wealth entirely depend on inclusive institutions and pluralist politics?

44. John A. Mathews, The renewable energies technology surge: A new techno-economic paradigm in the making?

The working paper series is edited by Rainer Kattel (kattel@staff.ttu.ee), Wolfgang Drechsler (drechsler@staff.ttu.ee), and Erik S. Reinert (reinert@staff.ttu. ee), who all of them will be happy to receive submissions, suggestions or referrals. 